\title{
AN APPRAISAL OF FACTORS RESPONSIBLE FOR ERRORS IN NIGERIAN CONSTRUCTION DOCUMENTS
}

*Dosumu, O.S. and Iyagba, R.A.

http://dx.doi.org/10.4314/ejesm.v6i1.6

\author{
Received 30th October 2012; accepted 11th January 2013
}

\begin{abstract}
The paper presents an empirical study of factors responsible for errors in Nigerian construction documents and aims at identifying the significant factors that are responsible for errors in the Nigerian construction documents. Information was obtained from both consultants (the producers of construction documents) and contractors (the user of construction documents) for the purpose of comparing the significant factors identified by the two sets of respondents. Out of the two hundred and sixty questionnaires administered, eighty six were retrieved and used for the analysis of the study. The statistical methods used for analysis are frequencies, percentages and mean item scores. The findings of the research show that while the contractors agreed that the consultants and management are the main factors responsible for errors in the Nigerian construction documents, the consultants agreed that the management and clients are the main factors responsible for them. However, the collective agreement of the consultants and contractors was that the consultants and management are the main factors responsible for errors in the Nigerian construction documents. The study concludes that the consultants and management are the main factors responsible for errors in the Nigerian construction documents and that they were just not willing to blame themselves for the misfortunes of Nigerian construction documents, hence they blame clients and management before themselves. The recommendation of the study is that to prevent and reduce errors in Nigerian construction documents, the significant factors that fall under the category of consultants and management need to be avoided when preparing construction documents.
\end{abstract}

Key words: Construction documents, Consultants/designers, Contractors, Errors, Nigeria

\section{Introduction}

In almost all countries, the construction industry has underperformed when compared with industries like manufacturing (Wan et al., 2006). The reason for this situation is most likely to be due to consultants' errors which are mostly noticed in the construction documents of proposed projects and at the construction stages rather than the design stages. Design, according to Love et al. (2008) is a complex, challenging and creative process that is often driven by personal motivation coupled with the desire to satisfy clients' needs. It is also the personal need to satisfy creative desire which is restrained within the confines of what is possible in the architectural and engineering process by economic constraint. The National Building Code (2006) however defined construction documents as contract drawings, schedules and specifications prepared by registered architects and registered engineers; priced bill of quantities prepared by registered auantitv survevors: aualitv management plan. Department of Building, University of Lagos, Akoka,

*Corresponding author email:osdosumu@unilag.edu.ng construction programme and project health and safety plan prepared by registered builders; conditions of contract and all-risk insurance for building works, personnel and equipment.

Error is an unsafe act and procedural violations of people at the sharp end (Reason, 2006). Unintended deviations from correct and acceptable practice that are avoidable (Love $e t$ al., 2008). Deviation from a code of behaviour; an act involving an unintentional deviation from truth or accuracy; an act that through ignorance, deficiency, or accident fails to achieve what should be done (The Webster's New encyclopaedic dictionary (1996) cited in Rauterberg and Felix (1996). Rooney, et al., (2002) defined error as any human action that exceeds the tolerances defined by the system with which the human interacts while Love and Josephson (2004) defined it as a deviation from what is intended and caused by human action.

Researchers (Norman, 1983; Palaneeswaran, et al., 2007) have traced many factors to errors in 
construction documents. However, the ones that are peculiar to Nigerian construction documents are yet to be identified and that is the problem to be solved by this study. Moreover, the effects of errors in construction documents are both numerous and devastating on construction projects. Some of the effects that are identified in literatures include design-induced rework (Love, 2002; Love et al., 2008), propagation of failure (Vrouwenvelder, et al., 2009), structural collapse, financial loss, inconvenience, deterioration of buildings, personal injury and sickness, time delay, damaged equipment (Barkow, 1995), defects, wastages and inconveniences (Palaneeswaran, et al., 2007), conflicts and ambiguities (Olatunji, 2011). Others are cost overrun (Mohammed, 2007), procurement systems (Rashid, et al., 2006), incomplete designs, change order, rework, construction delay, etc (Alarcon and Mardones, 1998).

As a result of the adverse effects of errors in construction documents, it is important to identify the factors that are responsible for them so that the professionals involved in the preparation of the documents can know the factors upon. When construction documents are error free, the reputations of the consultants involved would be improved and the rigours of re-designing and correcting errors would be eliminated. On the part of the client also, unrealistic estimates will be eliminated and confidence in consultants and contractors would be established for future projects. Excessive rigours of claims, variation/reworks are eliminated for the contractor and their profit is also increased. Better housing provisions are provided at lower cost for the citizens of the country and the contribution of the construction industry to national GDP will improve. Finally, global competition in international markets would be sustained and international recognition would be earned.

It is worth mentioning that it is not only consultants' errors that affect construction project success, construction errors also takes its toll on it. However, this study concentrates on errors in construction documents (consultants' errors) because it seems to neglected by Nigerian authors and it also appears to be a major area of error that adversely affects project success in any country. This was substantiated when Mohammed (2007) noted that project consultants play a major role in project cost overrun due to errors in construction documents.

The research carried out in Australia reveals that ninety-two percent $(92 \%)$ of the variation in their construction industry were attributable to errors in construction documents (Choy and Sidwell, 1991) and the consultant team share $60 \%$ of the variation. Diekman and Nelson (1985) also noted that the largest proportion of change orders and modifications originate from the owner (client) or their representatives (consultants) and these account for $46 \%$ of claims in federally funded projects. The study conducted by Burati et al. (1992) on nine fast-track industrial construction projects show that while construction deviations average $16 \%$ of the total number of deviations, design deviations averaged $78 \%$ of the total number of deviations. Hence, the need to determine the significant factors responsible for these errors in construction documents.

Some of the factors linked to errors in construction documents by various researchers in the construction industry include lack of consistency (Norman, 1983), re-use of notes and details of similar projects, wrong assumptions of standard practice, inexperience, lack of clarity and poor interface co-ordination, etc (Palaneeswaran, et al. 2007), unreliable and incompetent staff, acceptance of low design fee (Love et al., 2011), time boxing (Love et al., 2000). Other factors are planning/programming, stress, repetitive tasks (Shelton, 1999), limited attention, biases, modification of rules (Cheng-Wing and Davey, 1998), unavailable data, memory loss, misperception of data, over-reliance on default values, etc (Endsley, 1999). Further to these, Barkow (1995) identified negligence, lack of adequate design references, lack of knowledge, poor team work, human error, inadequate design checks, poor communications and complexity of task as factors causing errors in construction documents.

Contradiction of information, untried new technologies, adaptation of technology to human beings, physical and mental conditions (Vrouwenvelder et al., 2009), extra works, delays/disruption, conflicts, incompatibility/inconsistency, omission, inadequate detail/description, insufficient legibility (Long, 2011), motivation, cooperation, (Love and Josephson, 2004), carelessness, lack of diligence, 
ineffective use of computer aided design, unrealistic client demands, low task awareness, overload, fatigue, lack of awareness of changes in standards and not knowing what is required (Love, et al., 2008) are other causes of consultants' errors.

As a result of the enormity of these factors, they were classified into management related factors, consultants' factors, clients' factors, project characters and industry related factors (Mohammed, 2007). Atkinson (1998) categorized them into primary factors (e.g. self inspection, education/training), managerial factors (e.g. delegation of duties, change controlling, concurrent working control, communications) and global factors (e.g. organizational culture, economic pressure, time pressure, political pressure and societal pressure).

\section{Methodology}

A structured close ended questionnaire was designed to capture data on the factors responsible for errors in Nigerian construction documents. Two hundred and sixty copies of a questionnaire was administered on consultants (Architects, Engineers, Quantity Surveyors, Builders and others) and contractors in the Nigerian construction industry. Consequently, seventy-eight of them was returned thus giving a return rate of $30 \%$. The questionnaire was divided into socioeconomic characteristics of respondents and factors responsible for errors in Nigerian construction documents. The data for the study was basically collected from consultants and contractors whose offices are based in Lagos state, Table 1 General information of respondents

\begin{tabular}{lll}
\hline & Frequency & Percentage (\%) \\
\hline Position of respondents & & \\
Architecture & 26 & 33.3 \\
Civil/structural engineering & 8 & 10.3 \\
Quantity surveying & 10 & 12.8 \\
Building & 14 & 17.9 \\
Others & 20 & 25.6 \\
Total & 78 & 100.0 \\
Type of Services Rendered by Firms & & \\
Consultancy & 47 & 60.3 \\
Contracting & 31 & 39.7 \\
Total & 78 & 100.0 \\
Type of Project Handled by Firms & 39 & 50.0 \\
Public & 39 & 50.0 \\
Private & 78 & 100.0 \\
Total & & \\
\hline
\end{tabular}

Nigeria. Lagos state was chosen for the study not only because of accessibility to useable information, also because it houses the bulk of construction activities going on in Nigeria.

A list of Lagos based registered contractors was obtained from the register of the Corporate Affairs Commission (CAC) while those of consultants were obtained from professional Registration Boards like Architect Registration Council of Nigeria (ARCON), Council for Regulation of Engineering (COREN), Council of Registered Builders of Nigeria (CORBON) and Quantity Surveyors Registration Board of Nigeria (QSRBN). The reason for obtaining information from the contractors is to be able to compare their significant factors with those of the consultants. The questions on factors responsible for errors in the Nigerian construction documents were based on a 5 point Likert scale ranging from 1 , not significant to 5 , very significant so that statistical analysis could be used to extract the important factors from the non-important ones.

The reliability of the questionnaire used for the study was tested using the Cronbach's Alpha co-efficient which gave 0.908 for the sixty-three factors that were itemised. The data from the study was analysed using the Statistical Package for Social Sciences (SPSS 17). The frequencies, percentages, mean scores and analysis of variance were the statistical methods used to obtain the significant factors that are responsible for errors in the Nigerian construction documents. The results of the study were presented in tables. 


\begin{tabular}{lrl}
\hline Work Experience of Respondents & & \\
Less than 10years & 52 & 66.7 \\
10-15 years & 16 & 20.5 \\
16-20 years & 4 & 5.1 \\
Above 20 years & 6 & 7.7 \\
Total & 78 & 100.0 \\
Highest Educational Qualification of Respondents & & \\
Diploma & 16 & 20.5 \\
First degree & 46 & 59.0 \\
Second degree & 12 & 15.4 \\
Others & 4 & 5.1 \\
Total & 78 & 100 \\
Number of Employees in Organisations & & \\
1-10 & 16 & 20.5 \\
$11-50$ & 24 & 30.8 \\
Above 50 & 38 & 48.7 \\
Total & 78 & 100 \\
\hline
\end{tabular}

Table 1 shows the general information of respondents and their organizations. Architects were $33.3 \%$, civil/structural engineers were $10.3 \%$, quantity surveyors were $12.8 \%$, builders were $17.9 \%$ and other related professions were 25.6\%. This indicates that the respondents' professions were evenly spread. Also, $60.3 \%$ of the firms used for this study engage in consultancy while $39.7 \%$ engage in contracting. $50 \%$ of the organizations engage mostly in public projects and $50 \%$ engage mostly in private projects. $66.7 \%$ of the respondents for this study had less than 10 years of work experience, $20.5 \%$ had $10-15$ years of work experience, $5.1 \%$ had $16-20$ years work Table 2 Overall factors responsible for errors in construction documents

\begin{tabular}{|c|c|c|c|c|c|c|c|c|}
\hline $\mathrm{S} / \mathrm{N}$ & Factors & Category & Cons & Rank & Cont & Rank & Overall & Rank \\
\hline 1 & Designer experience & Designer & 4.15 & 2 & 4.68 & 1 & 4.36 & 1 \\
\hline \multirow[t]{2}{*}{2} & Lack of design reviews, value engineering & & & & & & & \\
\hline & studies and constructability & Designer & 3.97 & 5 & 4.52 & 2 & 4.21 & 2 \\
\hline 3 & Erratic decision making & Management & 4.19 & 1 & 4.16 & 9 & 4.18 & 3 \\
\hline 4 & Lack of coordination between disciplines & Management & 3.98 & 4 & 4.48 & 3 & 4.18 & 4 \\
\hline 5 & Lack of planning and inspection of project & Client & 3.97 & 5 & 4.30 & 6 & 4.11 & 5 \\
\hline 6 & Design management experience & Designer & 3.96 & 7 & 4.32 & 5 & 4.10 & 6 \\
\hline 7 & Lack of awareness of changes in standards & Designer & 4.04 & 3 & 4.13 & 10 & 4.08 & 7 \\
\hline 8 & Communications & Designer & 3.83 & 8 & 4.30 & 6 & 4.03 & 8 \\
\hline \multirow[t]{2}{*}{9} & Unclear and ambiguous Requirements for & & & & & & & \\
\hline & design specifications & Client & 3.75 & 10 & 4.33 & 4 & 4.00 & 9 \\
\hline 10 & Availability of information & Designer & 3.78 & 9 & 4.30 & 6 & 4.00 & 10 \\
\hline
\end{tabular}

$5=$ very significant, $4=$ significant, $3=$ Indifferent, $2=$ slightly significant, $1=$ not significant. $($ Cons $=$ Consultant, Cont $=$ Contractor, Overall= Contractors and consultant)

Table 2 reveals the contractors, consultants and overall means of the significant factors that are responsible for errors in Nigerian construction documents. Sixty-three factors were identified and classified into five categories (management, experience and $7.7 \%$ had over 20 years of work experience.

The educational qualifications of the respondents revealed that $20.5 \%$ of the respondents for the study had Diploma, 59\% had first degree, $15.4 \%$ had second degree and $5.1 \%$ had other degrees apart from the ones listed. This shows that majority of the respondents were first degree holders. The number of employees in the respondents' organizations was revealed to be $20.5 \%$ for $1-10$ employees, $30.8 \%$ for $11-50$ employees and $48.7 \%$ for more than 50 employees. 
factors influence errors in Nigerian construction documents is designer's experience (4.36), lack of design reviews, value engineering studies and constructability (4.21), erratic decision making (4.18), lack of co-ordination between disciplines (4.18), lack of planning and inspection of project (4.11), design management experience (4.10), lack of awareness of changes in standards (4.08), communications (4.03), unclear and ambiguous requirements for design specifications (4.00) and availability of information (4.00). This indicates that the consultants', management and client related factors are the most rated by both the consultants and the contractors. However, table 3 reveals that the consultants rated the management and clients' factors above the consultants. This may be due to the fact that they do not want to apportion blame of errors in construction documents to themselves, thus heap the blames of their misfortunes on other stakeholders (management and client).

Table 3 Factors responsible for errors in construction documents according to consultants

\begin{tabular}{lllll}
\hline S/N & Factors & Category & Consultants & Rank \\
\hline 1 & Erratic decision making & Management & 4.19 & 1 \\
2 & Insufficient fund to create quality document & Client & 4.17 & 2 \\
3 & Designer experience & Designer & 4.15 & 3 \\
4 & Lack of awareness of changes in standards & Designer & 4.04 & 4 \\
5 & Violations & Designer & 4.00 & 5 \\
6 & Construction start/finish time & Client & 4.00 & 6 \\
\hline
\end{tabular}

$5=$ very significant, $4=$ significant, $3=$ Indifferent, $2=$ slightly significant, $1=$ not significant.

The factor responsible for errors in Nigerian construction document as rated by consulting practitioners are erratic decision making (4.19), insufficient fund to create quality document (4.17), consultants' experience (4.15), lack of awareness of changes in standards (4.04), violations (4.00) and construction start/finish time (4.00). The consultants were not able to come up with many factors. However, out of the six they selected they agreed to possess three of the factors responsible for errors in the Nigerian construction documents.

Table 4 Factors responsible for errors in construction documents according to contractors

\begin{tabular}{|c|c|c|c|c|}
\hline $\mathrm{S} / \mathrm{N}$ & Factors & Category & Contractors & Rank \\
\hline 1 & Designer experience & Designer & 4.68 & 1 \\
\hline \multirow[t]{2}{*}{2} & Lack of design reviews, value engineering & & & \\
\hline & studies and constructability & Designer & 4.52 & 2 \\
\hline 3 & Lack of coordination between disciplines & Management & 4.48 & 3 \\
\hline 4 & $\begin{array}{l}\text { Unclear and ambiguous requirements for } \\
\text { design specifications }\end{array}$ & Client & 4.33 & 4 \\
\hline \multirow[t]{2}{*}{5} & Design management experience & Designer & 4.32 & 5 \\
\hline & Designer professional education & Designer & 4.32 & 6 \\
\hline 6 & Communications & Designer & 4.30 & 7 \\
\hline 7 & Availability of information & Designer & 4.30 & 8 \\
\hline 8 & Lack of planning and inspection of project & Client & 4.30 & 9 \\
\hline 9 & Design team efficiencies & Designer & 4.29 & 10 \\
\hline 10 & Inadequate documentation & Designer & 4.26 & 11 \\
\hline 11 & Design process & Designer & 4.19 & 12 \\
\hline 12 & Carelessness, lack of due diligence and negligence & Designer & 4.19 & 13 \\
\hline 13 & Erratic decision making & Management & 4.16 & 14 \\
\hline 14 & Lack of awareness of changes in standards & Designer & 4.13 & 15 \\
\hline 15 & Errors in design assumptions, concepts and & & & \\
\hline 16 & calculations & Designer & 4.11 & 16 \\
\hline 17 & Project manager's experience & Management & 4.06 & 17 \\
\hline
\end{tabular}


Table 4 shows that the factors identified by contracting organizations as being responsible for errors in the Nigerian construction documents are consultants' experience (4.68), followed by lack of design reviews, value engineering studies and constructability (4.52), Lack of coordination between disciplines (4.48), Unclear and ambiguous requirements for design specifications (4.33), design management experience (4.32), designer professional education (4.32), Communications (4.30), Availability of information (4.30), Lack of planning and inspection of project (4.30), design team efficiencies (4.29), Inadequate documentation (4.26), design process (4.19), carelessness, lack of due diligence and negligence (4.19), erratic decision making (4.16), Lack of awareness of changes in standards (4.13), Errors in design assumptions (4.11) and concepts and calculations (4.06). Out of the seventeen factors that were identified, the consultants had twelve while the management and client shared the remaining six. This shows that the consultants are the causes of errors in construction documents

Table 5 Factors responsible for errors in construction documents according to respondents that carry out public sector projects

\begin{tabular}{lllll}
\hline S/N & Factors & Category & $\begin{array}{l}\text { Public } \\
\text { respondents }\end{array}$ & Rank \\
\hline 1 & Designer experience & Designer & 4.31 & 1 \\
2 & Erratic decision making & Management & 4.28 & 2 \\
3 & Lack of coordination between disciplines & Management & 4.23 & 3 \\
4 & Lack of design reviews, value engineering studies and & & & 4 \\
& constructability & Designer & 4.18 & 5 \\
5 & Design management experience & Designer & 4.10 & 6 \\
6 & Lack of awareness of changes in standards & Designer & 4.08 & 7 \\
7 & Communications & Designer & 4.05 & 8 \\
8 & Carelessness, lack of due diligence and negligence & Designer & 4.03 & \\
\end{tabular}

$5=$ very significant, $4=$ significant, $3=$ Indifferent, $2=$ slightly significant, $1=$ not significant .

From table 5, the respondents that majorly carry out public projects noted in descending order that the factors responsible for errors in construction documents of public projects are designer's experience (4.31), erratic decision making (4.23), lack of co-ordination among disciplines (4.23), lack of design reviews, value engineering studies and constructability (4.18), designer management experience (4.10), lack of awareness of changes in standards (4.08), communications (4.05) and carelessness, lack of due diligence and negligence (4.03). This shows that the consultants, having shared six of the eight factors identified, are the main causes of errors in Nigerian construction documents.

While organisations that execute public projects identified eight factors, those that carry out private project identified seventeen factors as shown in table 6. Designer experience (4.41) topped the table, followed by lack of planning and inspection of project (4.32), insufficient fund to create quality document (4.24), lack of design reviews, value engineering studies and constructability (4.24), errors in design assumptions, concepts and calculations (4.20), availability of information (4.16), lack of coordination among disciplines (4.13), unclear and ambiguous requirements for design specifications (4.12), design management experience (4.10), erratic decision making (4.08), identification of project risk (4.08), lack of awareness of changes in standards (4.08), inadequate design time (4.04), deficient procedure for producing documents (4.04), completeness or co-ordination of information (4.04), attitude of client (4.04) and communications (4.00). This indicates that the organisations that work on private projects blame errors in construction documents on basically the consultants and the clients, although the management had two out of the seventeen factors. 
Table 6 Factors responsible for errors in construction documents according to respondents that carry out private sector projects

\begin{tabular}{|c|c|c|c|c|}
\hline $\mathrm{S} / \mathrm{N}$ & Factors & Category & $\begin{array}{l}\text { Private } \\
\text { respondents }\end{array}$ & Rank \\
\hline 1 & Designer experience & Designer & 4.41 & 1 \\
\hline 2 & Lack of planning and inspection of project & Client & 4.32 & 2 \\
\hline 3 & Insufficient fund to create quality document & Client & 4.24 & 3 \\
\hline 4 & $\begin{array}{l}\text { Lack of design reviews, value engineering studies and } \\
\text { constructability }\end{array}$ & Designer & 4.24 & 4 \\
\hline 5 & Errors in design assumptions, concepts and calculations & Designer & 4.20 & 5 \\
\hline 6 & Availability of information & Designer & 4.16 & 6 \\
\hline 7 & Lack of coordination between disciplines & Management & 4.13 & 7 \\
\hline 8 & Unclear and ambiguous requirements for design specifications & Client & 4.12 & 8 \\
\hline 9 & Design management experience & Designer & 4.10 & 9 \\
\hline 10 & Erratic decision making & Management & 4.08 & 10 \\
\hline 11 & Identification of project risk & Client & 4.08 & 11 \\
\hline 12 & Lack of awareness of changes in standards & Designer & 4.08 & 12 \\
\hline 13 & Inadequate design time (time boxing) & Designer & 4.04 & 13 \\
\hline 14 & Deficient procedure for producing document & Designer & 4.04 & 14 \\
\hline 15 & Completeness or contradiction of information & Client & 4.04 & 15 \\
\hline 16 & Attitude of client & Client & 4.04 & 16 \\
\hline 17 & Communications & Designer & 4.00 & 17 \\
\hline
\end{tabular}

\section{Discussion}

The study aimed at identifying the significant factors that are responsible for errors in the construction documents that are prepared in Nigeria. Unlike other studies (Mohammed, 2007; Love et al., 2009, Suther, 1998), the opinions of both the consultants and contractors were used for this study so that comparisons can be made between them. The study suggests that, although errors in construction documents are mostly related to consultants, contractors are also aware of the factors responsible for errors in construction documents, hence they are included in the study population. Also, the study compared the respondents that engaged in public projects with those that engage in private projects.

The results of this research show that the consultants are mostly responsible for the errors in Nigerian construction documents. This result is found to be consistent with that of Choy and Sidwell (1991) and contrary to Diekman and Nelson (1985) who found out that clients are responsible for larger proportion of change orders in federally funded projects. However, on privately funded projects, the clients' factors were rated second by respondents as being responsible for errors in Nigerian construction documents.
Also, out of the factors identified by the respondents as being responsible for errors in construction documents, consultants experience and lack of design reviews, corresponds with the results of Palaneeswaran, et al. (2007). Erratic decision making corresponds with Cheng-Wing and Davey (1998), design management experience was highlighted by Barkow (1995) and lack of awareness of changes in standards was identified by Norman (1983) and Love et al. (2008). Barkow (1995) also identified communication, Long (2011) pinpointed unclear and ambiguous requirements for design specifications and availability of information. According to the contractors, the factors responsible for errors in construction documents are consultants' experience, lack of design reviews, value engineering studies and constructability, lack of co-ordination between disciplines, etc. basically, the contractors blamed the consultants, management of projects and clients for the errors that occur in construction documents. This result is consistent with the findings of Love et al. (2008), Love and Josephson (2004) and Long (2011).

The respondents that carry out public sector projects agreed that consultants experience, erratic decision making, lack of co-ordination between 
disciplines, lack of design reviews, value engineer in studies and constructability, design management experience, lack of awareness of changes in standards, communication and carelessness, lack of due diligence and negligence are the significant factors responsible for errors in construction documents. The private project executors had more than the eight factors identified by the public sector project executors. This is likely going to be as a result of the autonomy of the private project clients. However, while the public projects respondents noted that the consultants and management factors are the generators of errors in construction documents; private project executors noted that consultants, clients and management factors are the significant factors responsible for errors in construction documents.

\section{Conclusion and Recommendation}

The aim of this study is to identify the major factors responsible for errors in Nigerian construction documents. The consultants and the contractors were the subject of the study and both their individual and collective responses were used for the analysis of the study. Also, respondents that carry out public and private projects were also used to determine the significant factors responsible for errors in the Nigerian construction documents. The findings of the study revealed that the consultants, management and client factors are core to the generation of errors in the Nigerian construction documents. However, among the three categories, the consultants' factors are found to be more responsible for the errors in Nigerian construction documents. The consultants' rating shows some disparity in the factors responsible for errors in construction documents as they rated management and clients' factors above their own.

Based on the finding of the research, the study concludes that in order to prevent the occurrence of errors in Nigerian construction documents, the consultants' experience, lack of design reviews, value engineering studies and constructability, design management experience, awareness of changes in standards, communications and availability of information (Designer's factors), erratic decision making, lack of co-ordination between disciplines (management factors) and lack of planning and inspection of project and unclear and ambiguous requirements for design specifications (client factor) should be worked upon by the stakeholders concerned in order to prevent the occurrence of errors in construction documents. It is also recommended that all the factors selected by both consultants and contractors should be avoided when preparing construction documents. Moreover, factors in excess of the ones collectively selected by both consultants and contractors should be put into consideration when preparing construction documents for public projects (table 5) and private projects (table 6).

\section{References}

Alarcon, L.F. and Mardones, D.A. (1998)

Improving the design construction interface,

Proceedings of IGLC-6, Sao Paulo, 1998.

Atkinson, A.R. (1998) The role of human error in the management of construction defects. COBRA 1998 conference.

Barkow, B. (1995) Human factors underlying building failures. National Research Council of Canada, Toronto, Ontario.

Burati, J.L. Farrington, J.J. and Ledbetter, W.B. (1992) Causes of quality deviations in design and construction. Journal of Construction Engineering and Management, 118(1) 34-49.

Cheng-Wing, S.L. and Davey, E.C. (1998) Designing to avoid human error consequences. HESSD, 1998

Choy, W.K. and Sidwell, A.C. (1991) Bills of

Quantities continued - Sources of variations in

Australian construction contracts. . Building

Economist, 30 (3) 25-30.

Diekmann. J.E. and Nelson, M.C. (1985) Construction claims: Frequency and severity." Journal of Construction Engineering and Management, 111 (1) 74-81

Endsley, M.R. (1999) Situation awareness and human error: Designing to support human performance. Proceedings of the High Consequence Systems Surety Conference, Albuquerque, NM, Federal Republic of Nigeria National Building Code (2006). Lexis Nexis Butterworks, South Africa

Long, R.J. (2011) Defective and deficient contract documents. Long International, Incorporated.

Love, P.E. (2002) Influence of project type and procurement method on rework costs in building construction engineering and projects. Journal of 
Construction Engineering and Management, 128

(1) $18-29$

Love, P.E., Edwards, D.J. and Han, S (2011) Bad apple theory of human error and building information modeling: A systemic model for BIM implementation. A paper presented at the 2011 proceedings of the $28^{\text {th }}$ ISARC, Seoul, Korea Love, P.E.D. and Josephson, P. (2004) Role of error-recovery process in projects. Journal of Management in Engineering, 20 (2) 70-79

Love, P.E.D., Edwards, D.J. and Irani, Z. (2008) Forensic project management: An exploratory examination of the causal behavior of designinduced rework. IEEE Transactions on Engineering Management, 55 (2) 234-247

Love, P.E.D., Mandal, P., Smith, J. and Georgiou, J. (2000) DECOREM: A design and construction rework minimization model. $1^{\text {st }}$ International Conference on Systems Thinking in Management, 2000, 377-382

Mohammed, R.E. (2007) An exploratory system dynamics model to investigate the relationships between errors that occur in construction documents in Saudi Arabia and their possible causes. An unpublished Ph.D thesis submitted to Heriot-Watt University School of the Built

Environment

Norman, D.A. (1983) Design rules based on analyses of human error. Communications of the ACM, 4 (26) 254-258

Olatunji, O.A. (2011) Scaffolding industry knowledge on errors in construction estimates. A paper presented at the 2011 proceedings of the $28^{\text {th }}$ ISARC, Seoul, Korea

Palaneeswaran, E., Ramanathan, M. and Tam, C. (2007) Rework in projects: Learning from errors. Surveying and Built Environment, 18(2), 47-58.
Rashid, R.A., Taib, I. M. and Ahmad, W.B. (2006) Bills of quantities- are they still useful and relevant today? Paper presented on the $21^{\text {st }}-25^{\text {th }}$ of June, 2006 at the international conference on construction industry at Padang, Indonesia.

Rauterberg, M. and Felix, D. (1996) Human errors: Disadvantages and advantages. Proceedings of the $4^{\text {th }}$ Pan Pacific Conference on Occupational Ergonomics, Department of Industrial Engineering, National Tsing Hua University, Hsinchu, 25-28.

Reason, J. (2006) Human error: Models and management. Retrieved on $14^{\text {th }}$ September, 2006 from www.bmj.com

Rooney, J.J., Heuvel, L.N. and Lorenzo, D.K. (2002) Reduce human error. Quality progress, 27-36

Shelton, C.P. (1999). Human interface/human error. Carnegie mellon.

Suther, R.A. (1998) Evaluating the perception of design errors in the construction industry. An unpublished Masters of Engineering report presented to the graduate committee of the Department of Civil Engineering, University of Florida.

Vrouwenvelder, T., Holicky, M. and Sykora, M. (2009) Modelling of human Error. Joint Workshop of COST Actions, Ljubljana, Slovenia, 21-22 September, 2009, 55-64

Wan, Y.W., Abdul, H.M., Mohd, S.M., Zakaria, M.Y. and Ahmadon, B. (2006) Development of quality culture in the construction industry. ICCI - 2006. 